\title{
REDUKSI JUMLAH BIJI CABAI RAWIT (Capsicum frutescents) DENGAN MENGGUNAKAN SARI AKAR ECENG GONDOK (Eichhornia crassipes)
}

\author{
Ferdia Windarti ${ }^{1}$ dan Tatang Sopandi ${ }^{2}$ \\ ${ }^{1}$ Mahasiswa Prodi Biologi Fakultas Matematika dan Ilmu Pengetahuan Alam Universitas \\ PGRI Adi Buana Surabaya \\ ${ }^{2}$ Dosen Program Studi Biologi Fakultas Matematika dan Ilmu Pengetahuan Alam \\ Universitas PGRI Adi Buana Surabaya \\ Koresponden Penulis Email : fwinda39@gmail.com
}

\begin{abstract}
Cayenne pepper is one of the important economic agricultural commodities and is widely used in the food industry. However, the presence of cayenne pepper seeds is not favored by some people because if consumed can cause digestive disorders. Giberelin is one of the growth regulating substances commonly used to produce seedless fruit growth. This study aims to explore the effect of water hyacinth root extract (Eichhornia crassipes) on plant height, yield and number of cayenne pepper seeds. The study was carried out experimentally using a completely randomized design (CRD) of 4 extract treatments, namely $0 \mathrm{~g} / 1$ (control), $25 \mathrm{~g} / 1,50 \mathrm{~g} / 1$, and $75 \mathrm{~g} / 1$ of water hyacinth root extract, each of which was repeated six times. The results of this study indicate that the provision of water hyacinth root extract can increase plant height and yield but reduce the amount of cayenne pepper seeds. The concentration of water hyacinth root extract $75 \mathrm{~g} / 1$ is the best water hyacinth root extract that can produce an average plant height of $65.67 \mathrm{~cm}$, an average yield of 206.50 fruits per plant with an average fruit yield of 170.17 gram per plant and the average number of seeds is 31.17 seeds per cayenne pepper. This study concluded that the root extract of goiter water can reduce the number of seeds and increase plant height and yield of cayenne pepper.
\end{abstract}

Keywords: cayenne pepper, giberelin hormone, water hyacinth and cayenne pepper seeds.

\section{PENDAHULUAN}

Cabai merupakan salah satu komoditas pertanian yang bernilai ekonomi penting dan banyak dimanfaatkan dalam industri pangan. Cabai rawit banyak mengandung minyak atsiri yang dapat memberi rasa pedas dan panas yang disebabkan oleh kandungan capsaisin $\left(\mathrm{C}_{18} \mathrm{H}_{27} \mathrm{NO}_{3}\right)$ yang tinggi terutama pada bagian biji. Sebagian masyarakat tidak menyukai rasa pedas pada cabai rawit.

Biji pada buah cabai tidak terlalu di perhatikan oleh masyarakat, tetapi biji tersebut jika dimakan dapat menyebabkan gangguan pada pencernaan (Pandolfini,
2009). Jumlah biji sedikit atau tanpa biji dianggap kurang menguntungkan karena mengurangi produksi biji atau benih, namun bermanfaat pada peningkatan kualitas dan produktivitas buah karena dapat memperlambat kematangan pada buah sehingga menambah waktu simpan (Pandolfini, 2009).

Buah tanpa biji banyak disukai oleh konsumen baik dalam bentuk buahbuahan untuk konsumsi segar misalnya, anggur, jeruk, dan pisang serta buahbuahan yang dikonservasi atau diproses misalnya, terong beku, saus tomat. Buah tanpa biji juga dapat meningkatkan kualitas buah ketika buah tersebut memiliki biji 
keras atau memiliki rasa yang buruk (Pandolfini, 2009). Buah tanpa biji dapat diperoleh melalui metode partenokarpi yaitu perkembahan buah tanpa pembuahan serta metode stenospermocarpy yaitu pengguruan biji-biji setelah pembuahan (Voraquaux, et al., 2000). Auksin, giberelin dan sitokinin atau campuran dari hormonhormon tersebut dilporkan terbukti efektif mendorong perkembangan buah tanpa pemupukan pada beberapa spesies tanaman, misalnya tomat dan terong (Gillaspy et al., 1993). Hormon auksin dan giberelin memainkan peran penting dalam mengatur proses perkembangan dalam tubuh tanaman (Guo et al.,. 2010). Giberelin (GAs) merupakan kelompok fitohormon yang berperan penting dalam mengkoordinasikan pertumbuhan buah dan pengembangan benih (Pandofilni, 2009). Giberelin membantu dalam pertumbuhan sel batang, daun dan bagian udara lainnya dengan menyebabkan perpanjangan sel, dan peningkatan panjang internodal (Rastogi et al, 2013). Konsentrasi giberelin yang lebih tinggi meningkatkan pertumbuhan tanaman (Bora dan Sarma, 2006).

Penghambatan pembentukan biji dengan partenokarpi pada buah biasanya dilakukan dengan cara mengaplikasi zat pengatur tumbuh, seperti giberelin pada bunga tanaman (Purnamaningsih et al., 2010; Rolistryo et al., 2014). Penggunaan giberelin banyak dilakukan oleh produsen anggur tanpa biji (Suwanto, 2002). Perlakuan giberelin ini mengakibatkan tidak terbentuknya biji karena gangguan pertumbuhan tabung sari sebelum pembuahan (Suwanto, 2002). Aplikasi hormon giberelin tebukti berpengaruh terhadap pembentukan buah tanpa biji pada semangka (Annisah, 2009). Selanjutnya Annisah (2009) mengemukakan bahwa pemberian hormon giberelin berpengaruh terhadap jumlah biji, ukuran dan bobot buah. Namun demikian, hormon giberelin yang banyak digunakan untuk menurunkan jumlah biji atau menghasilkan buah tanpa biji umumnya menggunakan hormon giberelin sintetis yang mahal dan ketersediaannya terbatas. Oleh karena itu perlu dicari sumber hormon giberelin dari bahan alam sebagai pengganti hormon giberelin sintesis.

Eceng gondok merupakan tanaman air yang dianggap gulma di lingkungan perairan karena penyebarannya sangat cepat dan tidak terkendali yang dapat menimbulkan banyak kerugian yakni mengurangi produktivitas lahan air yakni mengambil ruang, mengambil unsur hara yang juga dibutuhkan oleh ikan (Wardini, 2008). Namun demikian, enceng gondok diketahui mempunyai kandungan protein yang cukup tinggi yaitu antara 12-18\% serta kandungan asam amino cukup lengkap yang dapat dimanfaatkan sebagai pengganti hormon giberelin (Bayyinatul, et al., 2012). Akar eceng gondok (Eichhornia crassipes) diketahui mengandung hormon giberelin (Musbakri, 1999). Penelitian mengenai pemanfaatan sari akar eceng gondok untuk mengurangi jumlah biji pada tanaman buah khususnya cabai rawit belum pernah dipublikasikan. Penelitian ini bertujuan untuk mengeksplorasi efek pemberian sari akar eceng gondok terhadap pertumbuhan tinggi tanaman dan hasil panen cabai rawit, serta jumlah biji per buah cabai rawit.

\section{METODE PENELITIAN}

Penelitian ini telah dilaksanakan secara eksperimental pada bulan Februari sampai Juni 2018 di Kebun Percobaan Bungah Gresik menggunakan metode rancangan acak lengkap (RAL) terdiri atas 4 perlakuan pemberian konsentrasi sari akar eceng gondok yaitu $0,25,50$, dan 75 $\mathrm{g} / \mathrm{l}$ yang masing-masing diulang 6 kali.

\section{Pembuatan sari akar eceng gondok}

Pembuatan sari akar eceng gondok dilakukan dengan cara memilih akar eceng gondok yang masih segar (akar banyak dan 
tebal) dan tidak busuk. Akar eceng gondok dicuci dan dijemur selama 3 hari sampai berat konstan. Akar eceng gondok kering dilumatkan menjadi serbuk, ditimbang dan dibagi masing-masing dengan berat $375 \mathrm{~g}$, $750 \mathrm{~g}$, dan $1125 \mathrm{~g}$. Masing-masing serbuk akar eceng gondok tersebut dicampurkan dalam aquades sebanyak 1,5 1, sehingga diperoleh konsentrasi 25, 50, dan $75 \mathrm{~g} / \mathrm{l}$. Campuran diaduk homogen, dibiarkan selama 2 menit, disaring dan diperas untuk memperoleh sari akar eceng gondok.

\section{Aplikasi pada tanaman}

Sebanyak 24 batang bibit cabai rawit yang berumur 30 hari ditanam secara individu dalam polybag dengan media tanah dan pupuk organik dibagi 4 kelompok masing-masing 6 tanaman. Setiap kelompok disiram sari akar eceng gondok dengan konsentrasi $0,25,50$, dan $75 \mathrm{~g} / \mathrm{l}$. Perlakuan dengan pemberian sari akar eceng gondok tiap dua hari sekali dengan disiram setiap pagi dan sore hari sampai tanaman cabai rawit berbuah.

\section{Analisis statistika}

Semua data hasil pengamatan dianalisis statistika menggunakan analisis varian satu arah pada taraf signifikansi 0,05 . Uji lanjut untuk mengetahui letak perbedaan antar perlakuan dilakukan dengan menggunakan Uji BNT (Beda Nyata Terkecil) dengan taraf signifikansi 0,05 .

\section{HASIL DAN PEMBAHASAN Tinggi Tanaman Cabai Rawit}

Hasil penelitian memperlihatkan bahwa perlakuan penyiraman sari akar eceng gondok berpengaruh signifikan $(\mathrm{P}<0,05)$ terhadap tinggi tanaman cabai rawit. Gambar 1 menunjukkan bahwa tanaman cabai rawit tertinggi diperoleh pada penyiraman sari akar eceng gondok dengan konsentrasi $75 \mathrm{~g} / 1(65,67 \pm 2,25 \mathrm{~cm})$. Tinggi tanaman cabai rawit yang disiram sari akar eceng gondok $0 \mathrm{~g} / \mathrm{l}$ (kontrol) yaitu $57,83 \pm 2,31 \mathrm{~cm}$ signifikan $(\mathrm{P}<0,05)$ lebih rendah dibandingkan dengan penyiraman sari akar eceng gondok dengan konsentrasi $25 \mathrm{~g} / 1(62,17 \pm 1,83 \mathrm{~cm}), 50 \mathrm{~g} / 1(63,83 \pm 2,48$ $\mathrm{cm})$ dan $75 \mathrm{~g} / 1(65,67 \pm 2,25 \mathrm{~cm})$. Tinggi tanaman cabai rawit yang disiram akar eceng gondok dengan konsentrasi $25 \mathrm{~g} / \mathrm{l}$ signifikan $(\mathrm{P}<0,05) \quad$ lebih rendah dibandingkan dengan konsentrasi sari akar eceng gondok $50 \mathrm{~g} / 1$ dan $75 \mathrm{~g} / \mathrm{l}$. Tinggi tanaman cabai rawit yang disiram sari akar ecengan gondok dengan konsentrasi $50 \mathrm{~g} / 1$ signifikan $(\mathrm{P}<0,05) \quad$ lebih rendah dibandingkan $75 \mathrm{~g} / \mathrm{l}$.

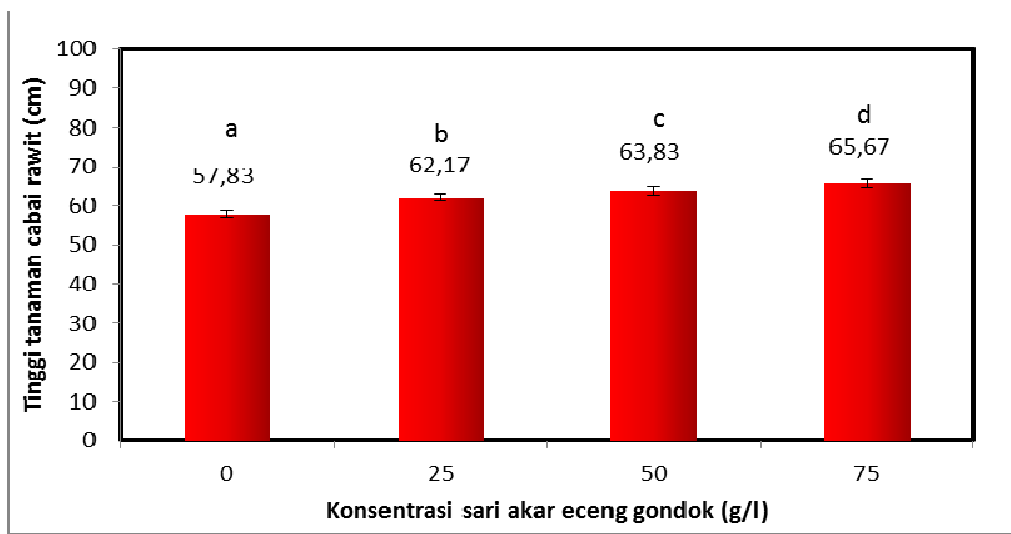

Gambar 1. Tinggi tanaman cabai rawit (Capsicum frutescents) setelah diberi perlakuan pemberian sari akar eceng gondok. 
Eceng gondok diketahui berfungsi sebagai sumber bahan organik yang dapat memperbaiki fisik tanah, menambah daya serap air dalam tanah, dan mampu meningkatkan pertumbuhan tanaman. Eceng gondok dapat memperbaiki sifat kimia tanah karena memiliki kandungan N-total 4,05\%, P-total 1,13\%, dan K-total 2,68\% (Mahbub et al., 2009). Peningkatan tinggi tanaman dan hasil panen cabai rawit akibat perlakuan pemberian sari akar eceng gondok mengandung hormon giberelin. Menurut Musbakri (1999), akar eceng gondok mengandung $0,18 \%$ hormon giberelin. Hormon endogen termasuk hormon giberelin yang disintesis pada jaringan meristematik antara lain daun, primordium cabang, akar dan biji dan sering digunakan sebagai zat pengatur tumbuh (Permatasari, et al, 2016). Giberelin yang terdapat pada sari akar eceng gondok berfungsi untuk merangsang pertumbuhan tanaman sehingga mengakibatkan peningkatan tinggi tanaman cabai rawit. Giberelin juga berperan dalam merangsang pembentukan polihidroksi asam sinamat yaitu senyawa yang menghambat kerja dari enzim IAA oksidase dimana enzim ini merupakan enzim perusak auksin. Giberelin memicu terbentuknya enzim $\alpha$-amilase yang akan memecah amilum sehingga kadar gula dalam sel akan naik, air diluar akan masuk kedalam sel yang dapat mengakibatkan sel memanjang. Hasil dari pemecahan amilum ini juga akan digunakan untuk respirasi oleh mitokondria sehingga menghasilkan ATP yang nantinya digunakan untuk energi dalam proses pembentangan sel (Permatasari, et al., 2016).

\section{Hasil panen cabai rawit Jumlah buah cabai rawit}

Hasil penelitian memperlihatkan bahwa penyiraman sari akar eceng gondok berpengaruh signifikan $(\mathrm{P}<0,05)$ terhadap jumlah buah cabai rawit. Gambar 2 menunjukkan bahwa jumlah buah tertinggi diperoleh pada penyiraman sari akar eceng gondok dengan konsentrasi $75 \mathrm{~g} / 1$ (206,50 $\pm 5,43$ buah per tanaman). Jumlah buah cabai rawit pada tanaman yang disiram sari akar eceng gondok dengan konsentrasi $0 \quad 0 \quad \mathrm{~g} / \mathrm{l} \quad$ (kontrol) yaitu $119,00 \pm 4,34$ buah per tanaman signifikan $(\mathrm{P}<0,05)$ lebih rendah dibandingkan dengan penyiraman sari akar eceng gondok dengan konsentrasi $25 \mathrm{~g} / 1 \quad(152,33 \pm 5,50$ buah per tanaman), $50 \mathrm{~g} / 1(172,17 \pm 5,19$ buah per tanaman) dan $75 \mathrm{~g} / 1$ (206,50 $\pm 5,43$ buah per tanaman). Penyiraman sari akar eceng gondok $25 \mathrm{~g} / 1$ signifikan $(\mathrm{P}<0,05)$ lebih rendah dibandingkan dengan penyiraman sari akar eceng gondok $50 \mathrm{~g} / 1$ dan $75 \mathrm{~g} / \mathrm{l}$. Penyiraman sari akar eceng gondok dengan konsentrasi $50 \mathrm{~g} / 1$ signifikan $\quad(\mathrm{P}<0,05) \quad$ lebih rendah dibandingkan dengan penyiraman sari akar $\begin{array}{llll}\text { eceng } & \text { gondok } & 75 & \mathrm{~g} / \mathrm{l} \text {. }\end{array}$ 


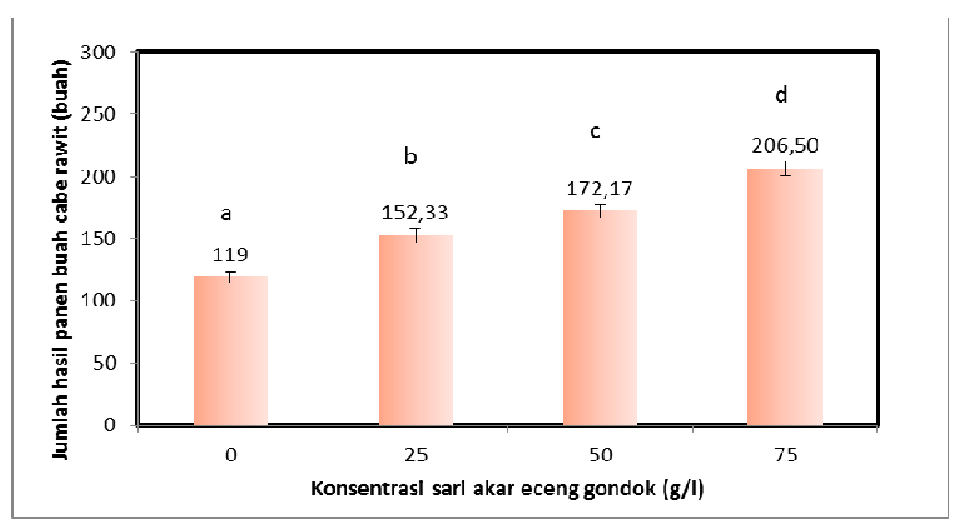

Gambar 2. Jumlah buah hasil panen cabai rawit (Capsicum frutescents) setelah diberi perlakuan pemberian sari akar eceng gondok.

Hasil penelitian ini mengindikasikan bahwa penyiraman sari akar eceng gondok dapat meningkatkan jumlah buah cabai rawit. Peningkatan jumlah buah tersebut diduga karena fungi hormon giberelin yang terdapat dalam akar yang untuk mempercepat pembungaan dan meningkatkan jumlah buah cabai rawit. Giberelin juga diketahui berperan dalam merangsang pembentukan polihidroksi asam sinamat yaitu senyawa yang menghambat kerja dari enzim IAA oksidase dimana enzim ini merupakan enzim perusak auksin. Giberelin memicu terbentuknya enzim $\alpha$ amilase yang akan memecah amilum sehingga kadar gula dalam sel akan naik, air diluar akan masuk kedalam sel yang dapat mengakibatkan sel memanjang. Hasil dari pemecahan amilum ini juga akan digunakan untuk respirasi oleh mitokondria sehingga menghasilkan ATP yang nantinya digunakan untuk energi dalam proses pembentangan sel (Permatasari, et al., 2016).

\section{Berat buah cabai rawit}

Hasil penelitian memperlihatkan bahwa penyiraman sari akar eceng gondok berpengaruh signifikan $(\mathrm{P}<0,05)$ berat buah hasil panen cabai rawit. Gambar 3 menunjukkan bahwa berat buah hasil panen cabai rawit tertinggi diperoleh pada penyiraman sari akar eceng gondok dengan konsentrasi $75 \mathrm{~g} / 1 \quad(170,17 \pm 4,83 \mathrm{~g}$ per tanaman). Berat buah hasil panen cabai rawit yang disiram sari akar eceng gondok dengan konsentrasi $0 \mathrm{~g} / \mathrm{l}$ (kontrol) yaitu $107,33 \pm 5,60 \mathrm{~g}$ per tanaman signifikan $(\mathrm{P}<0,05)$ lebih rendah dibandingkan dengan penyiraman sari akar eceng gondok dengan konsentrasi $25 \mathrm{~g} / 1 \quad(117,67 \pm 4,54 \mathrm{~g}$ per tanaman), $\quad 50 \mathrm{~g} / 1 \quad(159,17 \pm 5,19 \quad \mathrm{~g}$ per tanaman) dan $75 \mathrm{~g} / \mathrm{l}(170,17 \pm 4,83 \mathrm{~g}$ per tanaman). Berat buah hasil panen cabai rawit yang disiram sari akar eceng gondok dengan konsentrasi $25 \mathrm{~g} / \mathrm{l}$ signifikan $(\mathrm{P}<0,05)$ lebih rendah dibandingkan dengan konsentrasi $50 \mathrm{~g} / \mathrm{l}$ dan $75 \mathrm{~g} / \mathrm{l}$. Berat buah hasil panen cabai rawit yang disiram sari akar eceng gondok dengan konsentrasi 50 $\mathrm{g} / \mathrm{l}$ signifikan $(\mathrm{P}<0,05) \quad$ lebih rendah dibandingkan konsentrasi $75 \mathrm{~g} / \mathrm{l}$.

Hasil penelitian ini juga mengindikasikan bahwa penyiraman tanaman cabai rawit dengan sari akar eceng gondok dapat meningkatkan berat buah hasil panen. Peningkatan berat buah hasil panen tersebut diduga karena fungi hormon giberelin yang terdapat dalam sari akar eceng gondok. Menurut Wardini (2008), dalam tumbuhan eceng gondok terdapat 
hormon yang bekerja secara aktif dalam dinding sel sehingga dapat mempercepat pertumbuhan batang, daun dan sistem perakaran. Kandungan eceng gondok memiliki nitrogen yang cukup sehingga dapat meningkatkan sintesis protein untuk pembelahan dan pembesaran sel.

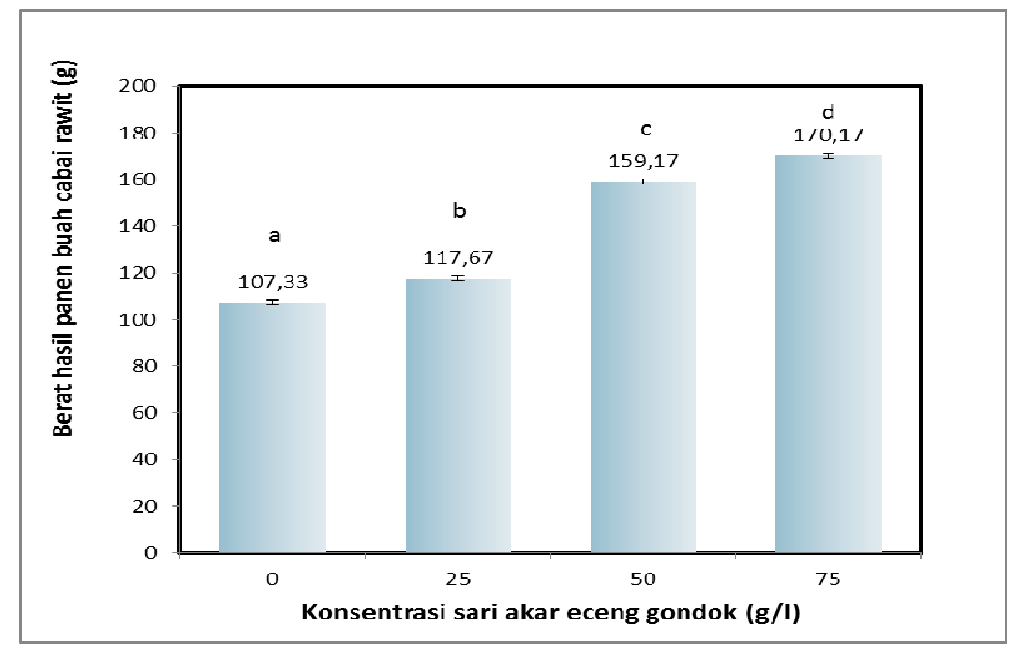

Gambar 3. Berat buah hasil panen cabai rawit (Capsicum frutescents) setelah diberi perlakuan pemberian sari akar eceng gondok.

\section{Jumlah Biji per Buah Cabai Rawit}

Hasil penelitian ini memperlihatkan bahwa pemberian sari akar eceng gondok berpengaruh signifikan $(\mathrm{P}<0,05)$ terhadap jumlah biji per buah cabai rawit. Gambar 4 . memperlihatkan jumlah biji per buah cabai rawit dari masing-masing perlakuan. Gambar 5 menunjukan jumlah biji per buah cabai rawit terendah diperoleh pada penyiraman sari akar eceng gondok dengan konsentrasi $75 \mathrm{~g} / 1 \quad(31,17 \pm 1,16$ biji per buah). Jumlah biji per buah cabai rawit yang disiram sari akar eceng gondok dengan konsentrasi $0 \mathrm{~g} / \mathrm{l}$ (kontrol) yaitu $44,33 \pm 1,21$ biji per buah signifikan $(\mathrm{P}<0,05)$ lebih rendah dibandingkan dengan jumlah biji per buah pada penyiraman sari akar eceng gondok dengan konsentrasi 25 $\mathrm{g} / \mathrm{l}(39,00 \pm 1,41$ biji per buah), $50 \mathrm{~g} / \mathrm{l}$ $(37,83 \pm 0,75$ biji per buah) dan $75 \mathrm{~g} / \mathrm{l}$ $(31,17 \pm 1,16$ biji per buah). Penyiraman sari akar eceng gondok dengan konsentrasi 25 $\mathrm{g} / \mathrm{l}$ tidak berbeda signifikan $(\mathrm{P}>0,05)$ dibandingkan dengan konsentrasi sari akar eceng gondok $50 \mathrm{~g} / \mathrm{l}$, namun signifikan $(\mathrm{P}<0,05)$ lebih rendah dibandingkan dengan konsentrasi sari akar eceng gondok $75 \mathrm{~g} / \mathrm{l}$. Jumlah biji buah cabai rawit yang disiram sari akar eceng gondok dengan konsentrasi $50 \mathrm{~g} / \mathrm{l}$ signifikan $(\mathrm{P}<0,05)$ lebih rendah dibandingkan dengan konsentrasi sari akar eceng gondok $75 \mathrm{~g} / 1$. 

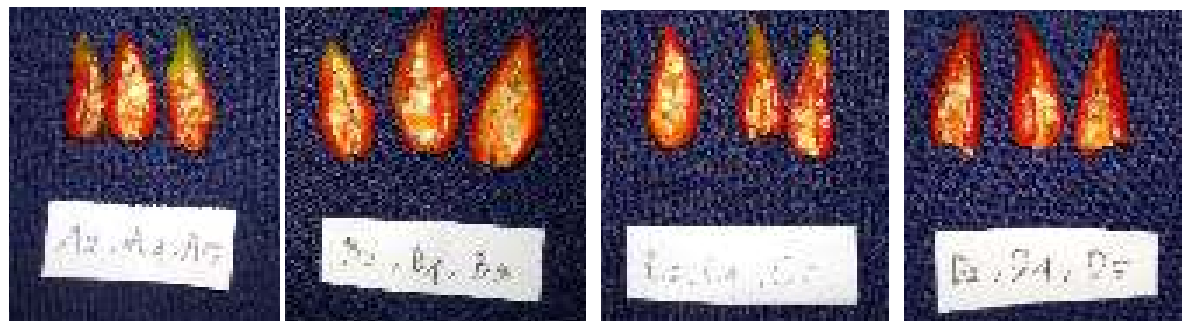

Gambar 4. Jumlah biji per buah cabai rawit (Capsicum frutescents) setelah diberi perlakuan pemberian sari akar eceng gondok.

Hasil penelitian mengindikasikan bahwa penyiraman sari akar eceng gondok dapat menurunkan jumlah biji buah cabai rawit. Penurunan biji buah tersebut diduga karena sari akar eceng gondok mengandung hormon giberelin yang berfungsi pada proses partenokarpi yaitu pembentukan buah tanpa biji. Menurut Permatasari, et al. (2016), pembentukan biji buah dapat dicegah dengan menggunakan hormon giberelin dengan cara menghambat proses fertilisasi. Hormon giberelin dapat mencegah buluh serbuk sari sampai ke mikropil dan mengakibatkan sel telur tidak bertemu dengan sel sperma sehingga tidak dihasilkan embrio. Lebih lanjut Permatasari, et al., (2016) mengemukakan bahwa perkembangan bakal biji akan terhenti apabila pembentukan embrio tidak terjadi dan biji tidak terbentu.

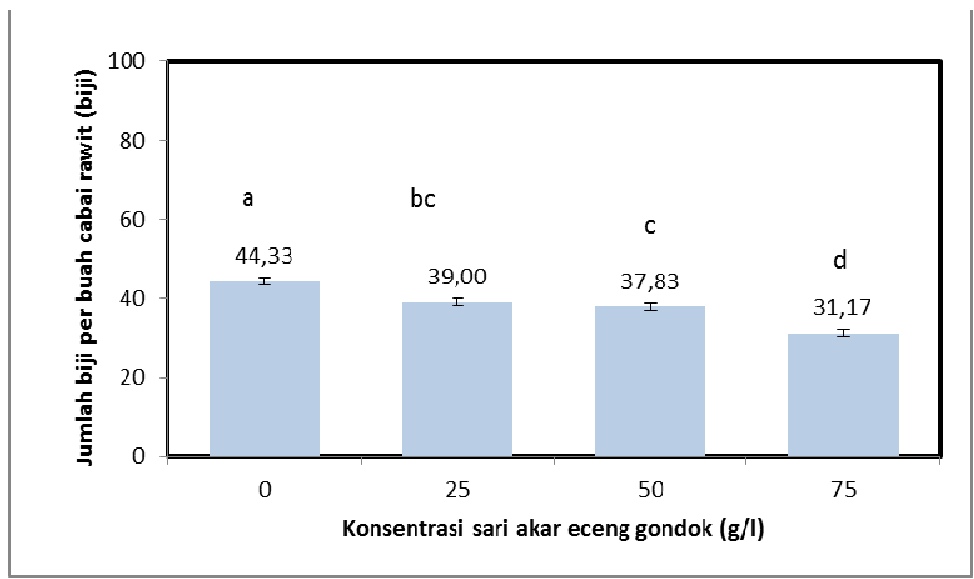

Gambar 5. Jumlah biji per buah cabai rawit (Capsicum frutescents) setelah pemberian sari akar eceng gondok.

\section{KESIMPULAN}

Hasil penelitian ini menyimpulkan bahwa penyiraman sari akar eceng gondok terbukti dapat meningkatkan tinggi tanaman, hasil panen baik jumlah dan berat buah cabai rawit, serta terbukti dapat menurunkan jumlah biji per buah cabai rawit. Konsentrasi terbaik yang diperoleh pada penelitian ini adalah $75 \mathrm{~g} / 1$.

\section{SARAN}

Penelitian ini menyarankan untuk menggunakan konsentrasi sari akar eceng gondok dengan konsentrasi yang lebih dari $75 \mathrm{~g} / 1$ untuk menurunkan jumlah biji dan 
meningkatkan hasil panen cabai rawit dan tinggi tanaman.

\section{DAFTAR PUSTAKA}

Annisah. 2009. Pengaruh Induksi Giberelin Terhadap Pembentukan Buah Partenokarpi pada Tanaman Semangka (Citrullus vulgaris Schard). Skripsi. Fakultas Pertanian. Universitas Sumatera Utara. Medan.

Anonim. 2011. Eceng Gondok. http://repository.usu.ac.id/bitstream/ 123456

789/31827/4/Chapter\%20II.pdf

(Diakses, 19 November 2013).

Asjayani, R. 2014. Aplikasi Ekstrak Daun Eceng Gondok (Eichhornia crassipes) Pada Level Dan Lama Simpan Terhadap Kualitas Telur Ayam Ras. Makassar: Program Studi Teknologi Hasil Ternak, Fakultas Peternakan, Universitas Hasanuddin Makassar.

Bayyinatul, M., R. Susilowati, dan A. Kusumastuti. 2012. Pemanfaatan Tepung Hasil Fermentasi Eceng Gondok (Eichornia crassipes) sebagai Campuran Pakan Ikan untuk Meningkatan Berat Badan dan Daya Cerna Protein Ikan Nila Merah (Oreochromis $\quad s p$ ). Jurnal. Universitas Islam Negeri. Malang.

Badan Pusat Statistik Republik Indonesia. (2014). Luas Panen, Produksi dan Produktivitas Cabai, 2009-2010. Diambil dari www.bps.go.id. [17 Januari 2018]

Exnasia, Y. 2010. Efektivitas Konsentrasi Giberelin (GA3) Pada Pertumbuhan Stek Batang Kopi (Coffea canephora) Dalam Media Cair.

Forth. 2008 dalam Muhtar A. 2008. Penggunaan Tanaman Enceng Gondok Sebagai Pre-Treatmen Pengolahan Air Minum Pada Air Selokan Mataram. Tugas Akhir Strata-1Teknik Lingkungan:
Tugas Akhir tidak diterbitkan. Yogyakarta: UII.

Gillaspy, G., Ben-David, H., Gruissem, W. 1993. Fruits: a developmental perspective. Plant Cell, 5 : 14391451.

Harjadi, SS. 2009.Zat Pengatur Tumbuhan. Jakarta : Penebar Swadaya

Hopkin, WG. 1995. Introduction to Plant Physiology. Jhon Wiley \& Sons, Inc. Singapore.

Muhammad, M, Zuraida, TM, dan Meldia S. 2009. Penerapan Pertanian Organik Yang Berkelanjutan di Lahan Pasang Surut Melalui Aplikasi Pupuk Organik Yang Indigenos. Laporan Penelitian Fakultas Pertanian Universitas Lambung Mangkurat Banjarbaru.

Muladi, S. 2001. Kajian Eceng Gondok sebagai Bahan Baku Industri dan Penyelamat Lingkungan Hidup di Perairan. Prosiding Seminar Nasional IV Masyarakat Peneliti Kayu Indonesia (MAPEKI). Samarinda.

Musbakri, 1999. Ekstraksi dan Identifikasi Giberelin Dari Akar Eceng Gondok (Eichhornia crassipes). Skripsi. Fakultas Teknologi Pertanian. Institut Pertanian Bogor.

Pandolfini, T., 2009. Seedless Fruit Production by Hormonal Regulation of Fruit Set. Nutrients, 1(2): 168177.

Pardal, S J, 2001. Pembentukan buah partenokarpi melalui rekayasa genetika. Buletin Agrobio 4(2): 4549.

Pardal, S.J., 2008. Tanpa Biji Tinggi Produksi. Trubus No. 468 Edisi November 2008/ XXXIX.

Permatasari, 2016. Pengaruh Pemberian Hormon Giberelin Terhadap Pertumbuhan Buah Secara Partenokarpi pada Tanaman Tomat Varietas Tombatu F1. LenteraBio Vol. 5 No.1: 25-31. 
Purnamaningsih. 2010. Perakitan Transgenik Mangga Varietas Gedong Gincu dan Transgenik Duku Varietas Kupeh Bersifat Seedless dengan Efisiensi Regenerasi $50 \%$ dan Transformasi 40 \%. J. Hort. 19(2). Hal 125-130.

Purnamaningsih. R., Kosmiatin, M. dan Apriana, A. 2010. Perakitan Transgenik Mangga Varietas Gedong Gincu dan Transgenik Duku Varietas Kupeh Bersifat Seedless Dengan Efisiensi Regenerasi $50 \%$ dan Transformasi 40\%. Laporan Akhir Program Riset Insentif (RIPP). Badan Penelitian dan Pengembangan Pertanian. Balai Besar Penelitian dan Pengembangan Bioteknologi dan Sumberdaya Genetik Pertanian. Kampus Penelitian Pertanian Cimanggu. Bogor.

Rastogi, RP., Sinha, RP., Incharoensakdi, A., 2013. Partial characterization, UV-induction and photoprotective function of sunscreen pigment, scytonemin from Rivularia sp. HKAR-4. Chemosphere: 93, 18741878.

Rolistyo. A., Sunaryo dan Tatik. W. 2014. Pengaruh Pemberian Giberelin Terhadap Produktivitas Dua Varietas Tanaman Tomat (Lycopersicum Esculentum Mill). Jurusan Budidaya Pertanian. Fakultas Pertanian. Universitas Brawijaya. Malang. Jurnal Produksi Tanaman, 2(6): 457-463.

Safira, E. U. 2011. Jurus Sukses Bertanam 20 Sayuran di Pekarangan Rumah. Klaten. 53.

Salim. 2013. Meraup Untung Bertanam Cabe Hibrida Unggu di Lahan dan Polybag. Yogyakarta: Lily Publisher.

Sarpian, T. 1999. Bertanam Cabai Rawit Dalam Polybag. Jakarta: Penebar Swadaya.
Sukman, Y. dan Yakup. 2002. Gulma dan Teknik Pengendaliannya. Raja Grafindo Persada. Jakarta.

Suwanto, A. 2002. Berbahayakah Semangka dan Anggur Tanpa Biji. Dikutip dari http://www.google.co.id/gwt/n?u=ht tp\%3A\%2F\%2Fwww2.kompas.com $\% 2$ Fkompascetak $\% 2$ F $0203 \% \mathrm{~F} 24 \% 2 \mathrm{FIPTEK} \% 2$ Fberb22.htm\& gwt pg $=0 \& h l=$ in\&s ource $=\mathrm{m}$. Diakses tanggal 1 April 2012.

Voraquaux, F., Blanvillain, R., Delseny, M., Gallois, P., 2000. Less is better: new approaches for seedless fruit production. Trend biotechnol: 18, 233-242.

Wardini. 2008. Analisis kandungan Nutrisi pada Eceng Gondok (Eicharnia crassipes).

http://digilib.itb.ac.id/gdl.php?mod= browser\&op $=$ read\&id $=$ jbptitbppgdl course 2001-r-631-sme. Diakses tanggal 11 Desember 2016.

Wulandari. D.C., Yuni, S.R., dan Evie, R. 2014. Pengaruh Pemberian Hormon Giberelin terhadap Pembentukan Buah Secara Partenokarpi pada Tanaman Mentimun Varietas Mercy. Jurusan Biologi, Fakultas Matematika dan Ilmu Pengetahuan Alam. Universitas Negeri Surabaya. Jurnal Lentera Bio 3(1): 27-32. 